\title{
Abandonment of Housing Projects in Nigeria: Appraisal of the Environmental and Socio-Economic Implications
}

\author{
Eugene Ehimatie Atamewan
}

\begin{abstract}
The rate of housing project abandonment in Nigeria is alarming and increasing by the day. Housing projects are supposed to be beneficial to both the individuals and society at large as it depicts the level of a country's development. But the incessant abandonment of these housing projects undoubtedly has some negative impact on the people, real property values, the construction industry and the built environment. This study aimed at reviewing the effects of housing project abandonment with the objective of identifying the causes in Akwa Ibom and Cross River States respectively. The study employed a combination of literature review site visitations, discussions with focal group (occupants and host of abandoned housing projects) and quantitative research approach using Linkert Scale structured questionnaires. The questionnaire were distributed to respondents mainly professionals in the building industry as well as users of abandoned housing project using purposive sampling method. The data collected was analyzed using Relative Importance Index (R.I.I). Findings reveal that 38 causes of project abandonment and 22 negative effects of abandonment of housing projects include defacing the aesthetics of the urban environment, visual defects on the environment/project site; distortions of the landscape/urban planning, structural failure of building, environmental pollution, increased health problems, threat to lives/insecurity, and decreased economic activities among others. The study recommended availability of funds for project execution, proper costing and appropriate schedule of project duration, transparency in selection of competent and trusted contractors, involvement of stakeholders in project selection and approval, policy of continuity of project by successive administration.
\end{abstract}

Keywords: Abandonment, Akwa-Ibom, built environment, building industry, Cross River, housing project

\section{INTRODUCTION}

The Nigerian building industry is plagued with several challenges, the central being abandonment of projects across the towns and cities of Nigeria. As a developing country, Nigeria is witnessing several incidences of uncompleted and abandoned building projects both from the private individuals and governments at all levels. Abandoned building projects create a negative impact on the environment and people due to its adverse effects on the built environment as well as posing serious threat to security and welfare of live of the individual and the environmental sustainability [1], [2].

However, it has been discovered that the problem of abandoned housing projects is not only the identity of Nigeria but a global phenomenon which is harmful to the stakeholders and the environment. The planning and initial construction of housing projects apart from giving a new and valuable product and services to the generality of the people also gives visual impressions to the environment, hence when these projects are abandoned or uncompleted; the people's aspiration/expectations are dashed [3], [4].
When a building project manifest in the inability to deliver on schedule, projected cost, quality specifications and inability to satisfy the end users, that project is termed a failed project. In most cases, uncompleted and abandoned projects are components of failed projects. Any building project that is uncompleted and does not provide users complete satisfaction by not fulfilling the expected purpose is regarded as abandoned building project. Thus, an abandoned building project is any project in which the construction work is incomplete and suspended [1], [5].

Housing means a complete bundle of goods and services that enhance good living and does not only refer to buildings or shelters but a combination of both the buildings, services, utilities and other components of the environment that connect man with the environment thus providing comfort for humans [6], [7]. Therefore, in discussing the effects of abandoned housing projects, other form of services that make the houses functional and liveable such as drainages, roads, water supply etc will also be highlighted but emphasis will be placed on buildings of all categories namely residential, commercial, institutional and recreational.

The rate of abandonment of housing projects in developing countries including Nigeria is worrisome and 
need to be urgently tackled as it is becoming a norm in our society eating deep into the national fabric.

Accordingly, it is no longer a surprise to see a project initiated and abandoned after the foundation laying ceremony. Thus, [8] expressed the worry that projects start failing and get abandoned from the initial stage of its construction both public and private building projects leaving the environment with a defaced landscape littered with several abandoned projects.

In Nigeria, initiation of development housing projects are no longer celebrated by the supposed end-users due to the pervasiveness of abandoned projects because from the onset, it is believed that the project will be uncompleted and abandoned. This is the highest level of distrust from citizenry to the government. Hence,[9] sum up this effect that sometimes, benefitting communities make projections about the outcome and probability of the project being out rightly abandoned by simply evaluating the reputation of the contractor selected to handle the project or the usual politicking of project by elected leaders.

Undoubtedly, abandoned housing projects create an unhealthy and unsafe environment. It is serious problem that need concerted effort and solution to reduce its incidence and put a stop to it. In Akwa Ibom and Cross River State, there are several uncompleted or abandoned housing projects all around the cities and towns ranging from privately owned or publicly owned housing projects including residential, commercial institutional and other forms of buildings. Therefore, this study appraised the causes of housing project abandonment and examines the negative effects of abandoned housing projects in the built environmental of Akwa Ibom and Cross River States respectively.

\section{LITERATURE REVIEW}

The contributions of the construction and building industry to the growth and development of any nation are enormous and unquantifiable. This is because it plays a key role in the socio-economic improvement of countries globally [10]. Therefore, the availability and functionality of the infrastructure in any nation enhance the well-being of individuals and the built environment at large.

In developing nations, building projects that are meant to bring succour and improve the welfare of the populace are usually abandoned by government agencies to the detriment of the people. In Nigeria today, the rate of abandonment of building construction projects is rising and alarming and has become a source of concern to the people as even building projects are abandoned soon after commencement [9].

Project abandonment refers to a situation in which a client refuse to provide maintenance and working services to a building; the incompletion and suspension of construction work in a project [9], [5]. An abandoned building project means any building project that is unusable, uninhabitable, non-functional and uncompleted.

Although the thrust of this study is not on the causes of housing project abandonment, it is important to outline the causes so to have a clearer understanding of the effects.
Several reasons have been adjudged to be responsible for housing project abandonment in Nigeria and other developing countries. Although, a few of this causes are natural and climatic factors such as death of client and poor weather conditions, which are unforeseen and beyond the control of humans, most of the major causes are purely controllable with proper planning and effective management of available funds in addition to prioritization. Several authors namely [11], [12, [13, [14],[15], [16] and [17] agreed that the major cause of housing project abandonment is lack of adequate funding, noting that the commencement and completion of any project is determined on the level of funding available.

The problem of inconsistencies in government policies due to regular change in government is another cause of project abandonment as successive administration abandons uncompleted projects from previous government and embarks on new projects for political and other reasons [18], [11]. In addition, interruptions and interference by community leaders, youth and other organizations in project developments in communities across the states of Nigeria is another major cause of project abandonment. Most times these categories of people demand for 'settlement' in form of compensation which is usually unreasonably high before projects are cited in their areas [11], [13], [19].

Other causes of housing project abandonment as outlined by various authors such as [20], [21],[22],[4],[23],[14] and [17] are: inadequate/improper planning; inflation; bankruptcy of contractor; variation of project scope; delaying in payment; incompetent project managers; wrong estimates; faulty designs; poor timing (poor estimation of project duration; poorly developed clients' brief and working drawings; unrealistic cost planning and control at the design stage; lack of organized work program planning and lack of stake holders' involvement among others.

Conversely, the negative impact of housing project abandonment cannot be underestimated as it affects the individuals, economy and the built environment. On the individuals, the wellbeing and health of inhabitants of abandoned housing projects are affected due to the health hazards posed by the environment as waste dump. Consequently, abandoned housing projects can cause common health challenges such as diarrhoea, typhoid fever, malaria and other dirt associated health problems to the inhabitants of the area [24]. On the environmental effect,[9]asserted that abandoned housing projects have adverse effects on the entire environment by defacing the aesthetics, making the abandoned sites vagrant's attractions and hideout for criminal activities, thereby posing a threat to the security of lives and the sustainability of the environment.

Economically, abandoned housing projects are a waste of valuable resources, causing decline in property value and loss of community aesthetics values [11], [25]. In their submissions, [19],[4] and [26] summed up the effects of abandonment of housing project generally to include reduction in employment opportunities, wastage of resources, decreases in tempo of construction activities, decrease in revenue accruable to government, disappointment of populace/users; lowering of living standard; pollution of environment; structural failure 
(collapse of building), migrationand difficulty in attracting foreign loans.

However, most of the researchers anchored their studies on the causes on abandoned projects only and offered possible solutions to the problems. But only few researchers have carried out study on the effects of project abandonment, hence this study reviewed in detail recent works of two authors based on their relevance to this study.

A study by [16] on the 'professional views on the causes and effects of construction projects abandonment in Ibadan, Nigeria is also worth reviewing. The study which was descriptive employed structured questionnaire administration with Linkert scale design approach and distributed to 70 consultants made up of Architects, Engineers, Quantity Surveyors and Builders. The data was analyzed using statistical formulae to calculate the relative importance index (RII). Findings of the study identified 23 important causes of abandonment of projects which include inadequate funding, payment remittance delay, death of client/owner and improper project design and planning among others. In addition, the study established the effects of abandonment to include loss of strength of structural members, visual defects to the surrounding site, hidden places for dangerous animals, pollution and marginalization of population. The authors recommended adequate funding of projects, adequate policies and its continuity by successive government and adequate planning of project with detailed design and costing.

Similarly,[26] carried out a study on 'Effects of Abandoned Urban Infrastructure on Environmental Development in Ogun State, the aim of the study was to examine the effects of abandoned infrastructure on the environment with the objective of identifying the causes and types of abandoned infrastructure in Ogun State, Nigeria. The study used research methodology of questionnaire administration and interviews to obtain data from estate surveyors, valuers, and end users (road users, students and residents of housing estates) which also form the focal group for the study. Descriptive analysis and the Relative Importance Index (RII) were employed in analyzing the data collected. Findings of the study revealed that environmental degradation, increase in health issues and decrease in business activities are among the ten effects of abandonment. The study recommends the cleaning of construction site and it environment, adopting public private partnership (PPP) in project execution and, use of turnkey project and stage-by-stage construction model.

\section{A. Effects of Abandonment of Housing Projects in Nigeria}

Based on project site visitations and discussions with stakeholders in the Building industry in addition to the view expressed specifically on the study of these authors namely; [11], [4], [15], [16], [5] and [26], this study therefore summarize the effects of housing project abandonment as follow:

(1) Population of users getting disappointed of the proposed project

2) Lowering of the living standard

3) Wastage of valuable resources

(4) Opportunities of employment become lower
(5) Economic activities decrease

(6) Decrease in the revenue accruing to government

(7) Foreign loans are more difficult to obtain.

(8) Wastage of equipment in site

(9) Increase in final cost of project

(10) Declining of the property values

(11) Declining of the property conditions

(12) Environmental pollution through garbage disposal

(13) Structural failure of building

(14) Visual defects on the environment/project site

(15) Distortions of the landscape/urban planning of the environment

(16) Insecurity of lives of due to its use as criminal hideout

(17) Health problems

(18) Defacing the aesthetics of the urban environment

(19) Threat to the environment/homes to dangerous animals

(20) Marginalization of the host population

(21) Conflict between public administration and the private sector.

(22) Lack of trust on the government by the citizenry

\section{METHODOLOGY}

The study employed a combination of literature review, project site visitations and quantitative research approach using Linkert Scale structured questionnaires and discussions with focal group (occupants and host of abandoned housing projects). The literature review produced the basis for the meaning, causes and the effects ofabandoned housing project in Nigeria.The first phase of the questionnaire preparation was the discussions with the focal group directly affected by the problem of abandonment which produced some other effects not listed in the literature. The additional information collected helped in the formulation of the questionnaire for administration as the second phase.Thus, 170 structured questionnaires centred on the effects of housing project abandonment were distributed to respondents mainly building clients, building contractors, architects, builders, surveyors and planners in both Akwa Ibom and Cross River States using purposive sampling method. The purpose of this phase of questionnaire administration was for the respondents to rate the effects of abandoned housing projects according to its significance.

A total of 125 of the questionnaires were returned representing 73.53\%. A 4-point Linkert scale instrument as follows: Strongly Agreed $(\mathrm{SA})=4$; Agreed $(\mathrm{A})=3$; Disagreed $(\mathrm{D})=2$; and Strongly Disagreed $(\mathrm{SD})=1$

The data collected was analyzed using Relative Importance Index (RII) applying the adopted formulae:

R.I.I. $=(4 n 4+3 n 3+2 n 2+n 1) / 4 N$

Where: $\mathrm{n} 4=$ Strongly Agree (SA); n3 = Agree (A); n2 = Disagree (D); $\mathrm{n} 1$ = Strongly Disagree (SD); $\mathrm{N}=$ number of respondents.

\section{DISCUSSIONS AND FINDINGS}

Discussions with the focal group centred on the additional effects of housing project abandonment which were not 
listed in the literature as well as the significance and rating of the effects on the individuals, the economy and the environment respectively. The discussions proved that the effects of abandoned housing projects in Nigeria in general and Akwa Ibom and Cross River States in particular were not exhaustive. Thus, in addition to the effects outlined by various scholars cited above, the study showed the effects to include distortions of the landscape/urban planning; lack of trust on the government by the citizenry; betrayal of citizenry by the govt or client; increased debt profile of contractor; frustration and death and re-awarding/variation of contract with increased project cost.

TABLE 1: Effects of Housing Project Abandonment

\begin{tabular}{|c|c|c|c|c|c|c|}
\hline S/N Effects of Abandonment & 1 & 2 & 3 & 4 & RII & $\overline{a n k}$ \\
\hline $\begin{array}{l}\text { 1.Disappointments of the } \\
\text { end-users }\end{array}$ & 0 & 10 & 20 & 95 & 0.920 & 7 \\
\hline 2.Lowering of the living std. & 0 & 15 & 30 & 80 & 0.880 & 17 \\
\hline 3. Wastage of valuable resources & s 0 & 17 & 20 & 93 & 0.932 & 6 \\
\hline $\begin{array}{l}\text { 4. Lowering of employment } \\
\text { opportunities }\end{array}$ & 0 & 10 & 30 & 85 & 0.900 & 14 \\
\hline $\begin{array}{l}\text { 5. Decreased economic } \\
\text { activities }\end{array}$ & 0 & 5 & 45 & 75 & 0.890 & 16 \\
\hline $\begin{array}{l}\text { 6. Decrease in government } \\
\text { revenue }\end{array}$ & 0 & 20 & 40 & 65 & 0.840 & 20 \\
\hline $\begin{array}{l}\text { 7. Difficulty in obtaining } \\
\text { foreign loans }\end{array}$ & 10 & 30 & 35 & 50 & 0.750 & 22 \\
\hline 8. Wastage of equipment on site & 0 & 12 & 33 & 75 & 0.846 & 19 \\
\hline $\begin{array}{l}\text { 9. Increase in final cost of } \\
\text { project }\end{array}$ & 0 & 5 & 35 & 85 & 0.910 & 10 \\
\hline $\begin{array}{l}\text { 10. Declining of the property } \\
\text { values }\end{array}$ & 0 & 10 & 26 & 89 & 0.908 & 11 \\
\hline $\begin{array}{l}\text { 11. Declining of the property } \\
\text { conditions }\end{array}$ & 0 & 12 & 25 & 88 & 0.902 & 13 \\
\hline $\begin{array}{l}\text { 12. Environmental pollution } \\
\text { through waste disposal }\end{array}$ & 0 & 5 & 23 & 97 & 0.934 & 5 \\
\hline 13. Structural failure of bdg. & 0 & 5 & 25 & 100 & 0.950 & 3 \\
\hline $\begin{array}{l}\text { 14. Visual defects on the } \\
\text { environment/project site }\end{array}$ & 0 & 5 & 20 & 100 & 0.940 & 4 \\
\hline $\begin{array}{l}\text { 15. Distortions of the } \\
\text { landscape/urban planning }\end{array}$ & 0 & 0 & 20 & 105 & 0.960 & 2 \\
\hline $\begin{array}{l}\text { 16. Criminal hideout } \\
\text { posing insecurity to lives }\end{array}$ & 0 & 10 & 33 & 82 & 0.894 & 15 \\
\hline 17. Health problems & 0 & 5 & 33 & 87 & 0.914 & 9 \\
\hline $\begin{array}{l}\text { 18. Defacing the aesthetics } \\
\text { of the urban environment }\end{array}$ & 0 & 0 & 15 & 110 & 0.970 & 1 \\
\hline $\begin{array}{l}\text { 19. Hidden places for } \\
\text { dangerous animals posing threat }\end{array}$ & 0 & 0 & 40 & 85 & 0.920 & 7 \\
\hline $\begin{array}{l}\text { 20. Marginalization of the } \\
\text { host population }\end{array}$ & 0 & 15 & 35 & 75 & 0.870 & 18 \\
\hline $\begin{array}{l}\text { 21. Conflict between public } \\
\text { admin and the private sector }\end{array}$ & 0 & 25 & 35 & 65 & 0.830 & 21 \\
\hline $\begin{array}{l}\text { 22. Lack of trust on the } \\
\text { government by the citizenry }\end{array}$ & 0 & 15 & 18 & 92 & 0.904 & 12 \\
\hline
\end{tabular}

Source: Authors' Fieldwork, 2020.

Table 1 above shows the Relative Importance Index (RII) of the effects of housing project abandonment in Nigeria in general and particularly in the study areas of Akwa Ibom State and Cross River State respectively. These effects are both environmental and socio-economic in nature. The study confirmed that twenty-two (22) effects were of significance. These effects are negative and are rated based on their level of significance beginning from the most significance to the least significance as expressed by the views of the respondents in the study areas. Defacing the aesthetics of the urban environment (R.I.I. 0.970) is ranked 1st; Distortions of the landscape/urban planning (R.I.I. 0.960 is ranked $2^{\text {nd }}$ ); Structural failure of building (R.I.I. 0.950 is $3^{\text {rd }}$ ); Visual defects on the environment/project site (R.I.I. 0.940 is $4^{\text {th }}$ ); Environmental pollution (R.I.I. 0.934 is $5^{\text {th }}$; Wastage of valuable resources (R.I.I. 0.932 is $6^{\text {th }}$ ); Hidden places for dangerous animals posing threat (R.I.I. 0.920 is ranked7th); Disappointments of the end-users (RI.I.I 0.920 is ranked 7th); Health problems (R.I.I. 0.914 is ranked $9^{\text {th }}$ ); Increase in final cost of project (R.I.I. 0.910 is ranked $10^{\text {th }}$ ); Declining of the property values(R.I.I. 0.908 is ranked $\left.11^{\text {th }}\right)$; Lack of trust on the government by the citizenry (R.I.I. 0.904 is ranked $12^{\text {th }}$ ); Declining of the property conditions (R.I.I. 0.902 is ranked $13^{\text {th }}$ ); Lowering of employment opportunities (R.I.I. 0.900 is ranked $14^{\text {th }}$ ); Criminal hideout posing insecurity to lives (R.I.I. 0.894 is ranked $15^{\text {th }}$ ); Decreased economic activities (R.I.I. 0.890 is ranked $16^{\text {th }}$ ); Lowering of the living standard (R.I.I. 0.880 is ranked $17^{\text {th }}$ ); Marginalization of the host population (R.I.I. 0.870 is ranked $18^{\text {th }}$ ); Wastage of equipment on site (R.I.I. 0.846 is ranked $\left.19^{\text {th }}\right)$; Decrease in government revenue (R.I.I. 0.840 is ranked $20^{\text {th }}$ ); Conflict between public admin and the private sector, (R.I.I. 0.830 is ranked $21^{\text {st }}$ ) while Difficultyin obtaining foreign loans (R.I.I. 0.750 is ranked $\left.22^{\text {nd }}\right)$.

Findings revealed that the most significant impact or negative effects of housing project abandonment is on the environment. This is followed by health challenges/ insecurity and threat to lives then followed by socialeconomic challenges. Some of the findings are in agreement with earlier findings by [4];[16] and [26].

\section{CONCLUSION}

The study identified that housing projects are abandoned everywhere in Nigeria in general and Akwa Ibom and Cross River States in particular. The study established that housing projects abandonment has negative impact on the people, the economy and the environment by making the environment unhealthy and unsafe thereby threatening the sustainability of the built environment. In general, the study has established that projects abandonment is a major contributing factor to both urban and socio-economic decay in the study areas.

However, the effects of housing project abandonment is basically classified as environmental, structural and socioeconomic which means it affects the environment by defacing the aesthetics of the urban environment, distortions of the landscape/urban planning and environmental pollution through waste disposal. Structural effects are failure or decay of building component which leads to reduction in life span of the building making the building prone to collapse as well as decline in the property value. The socio-economic effects include disappointments of the end-users, lowering of employment opportunities, decreased economic activities, lowering of the living standard lack of trust on the government by the citizenry, declining of the property conditions and decrease in government revenue among others.

The study concludes that since it is evident that the major causes of project abandonment are connected with 
finance, lack of trust/accountability, professional incompetence, political factors and lack of stakeholders' involvement in project selection, the study recommends as follows:

i. availability of needed funds before initiation of particular housing project

ii. Proper costing and appropriate schedule of project duration with due considerations of human controllable factors and uncontrollable/ unforeseen factors

iii. Transparency in selection of competent and trusted contractors

iv. Involvement of stakeholders in project selection and approval

v. Policy of continuity of project by successive administration.

\section{ACKNOWLEDGMENT}

The author wish to thank the respondents in the built environment and building professionals namely the architects, engineers, planners, contractors in both Akwa Ibom and Cross River State and the focal group members for their cooperation and understanding. Their candid responses contributed immensely to the success of this research. The contributions of the author's research assistants, some of whom are Post graduate students of the Faculty of Architecture; Cross River University of Technology Calabar, Nigeria cannot be underestimated. They helped in the administration of the questionnaires. Your contributions are highly appreciated.

\section{REFERENCES}

[1] M. E. Hanachor, "Community Development Project Abandonment in Nigeria: causes and effects," Journal of Education and Practice, $3(6), 33-36,2012$

[2] O. A. Akindele, "Environmental Effects of abandoned properties in Ogbomoso and Osogbo Nigeria," Ethiopian Journal of Environmental Studies and Management, vol. 6, no. 2, pp.707-716, 2013.

[3] R. H Abdul, A. M Alashwai, M. Ayub, and A. A Abdullah, "Abandoned Housing Projects in Malaysia: Pressing issues during the rehabilitation process," International Journal of Architectural Research, vol. 7, iss. 1. pp. 65-73, 2013.

[4] A. E. Olusegun, and A. O. Michael, "Abandoned of Construction Project in Nigeria: Causes and Effects," Journal of Emerging Trends in Economics and Management Sciences, vol. 2, no. 2, pp. 142-145, 2011

[5] S. A. Dada, "An evaluation of the environmental factors that lead to abandonment of public building projects in the Federal Capital Territory, Abuja," M.Sc Thesis, Dept. Building, Ahmadu Bel $\neg$ lo University, Zaria, 2016.

[6] A. F. Lanrewaju, "Urbanization, housing quality and environmental degeneration in Nigeria," Journal of Geography and Regional planning; vol. 5 no. 16, pp. 422-429, 2012.

[7] E. E. Atamewan, "Development of minimum housing design standards for low-income residential dwellings in Bayelsa State, Nigeria," Ph.D. dissertation, Dept. Architecture, Federal University of Technology, Minna, Nigeria, 2017.

[8] C. C. Nwachukwu and S. M. Nzotta, "Quality Factor Indexes: A Measure to Project Success Constraints in A Developing Economy”, Interdisciplinary Journal of Contemporary Research in Business, vol. 2 no. (2), pp. 1-8. 2010.

[9] O. Olalusi and A. Otunola,"Abandonment of Building Projects in Nigeria - A Review of Causes and solution, presented at ICCEE Dubai, March 24-25, pp. 253-255. 2012.

[10] N. D. Usman, P. K. Kamaru, and C. Mireri, "The Influence of Implementation Phase Principles on Project Performance within the building industry in Abuja, Nigeria," Journal of Environmental Science and Resources Management, vol. 6, no. 1, pp. 125-13, 2014.
[11] F. O. Efenudu, "Causes and Effect of Abandonment of Project on Property Value; A Case of Port Harcourt," B.Sc. Thesis, Dept. Estate Management, Rivers State University of Science and Technology, Nigeria, 2010

[12] P. W. Ihuah, and J. C. Fortune, "Toward a Framework for the Sustainable Management of Social (Public) Housing Estates in Nigeria,"Journal of US-China Public Administration, vol. 10, no. 9, pp. 901-913, 2013.

[13] P. W. Ihuah, and D. Eaton "A Framework for the Sustainable Management of Social (Public) Housing Estates in Nigeria: a pilot study," A Paper Presented at RICS COBRA Research Conference, New Delhi, India, 2013.

[14] A. J. Gana, and K. O. Olorunfemi, "Human Elements and factor contribution and consideration in construction Projects towards completion (the Nigeria Experience)," International Research Journal of Engineering Science, Technology and Innovation, vol. 4, no. 1, pp.12-18, 2015.

[15] S. V. Doraisamy, Z. A. Akasah, and R. Yunus, A Review on Abandoned Construction Projects: Causes \& Effects. Applied Mechanics and Materials. Vols. 773-774; pp 979-983, 2015.

[16] M. A. Tijani and W. Ajagbe, "Professional views on the causes and effects of construction projects abandonment in Ibadan Metropolis, Nigeria," Ethiopian Journal of Environmental Studies and Management. vol. 9, no. 5, pp. 593-603, 2016.

[17] D. Mac-Barango, "Construction Project Abandonment: An Appraisal of Causes, Effects and Remedies," World Journal of Innovation and Modern Technology. vol. 1, no. 1, 2017.

[18] O. O. Aluko, "Construction project abandonment in Nigeria: A Threat to National Economy," Knowledge Review, vol. 16, Iss. 3, pp. 18-23, 2008.

[19] E. O. Ayodele, and O. M. Alabi, "Abandonment of Construction Projects in Nigeria: Causes and Effects," Journal of Emerging Trends in Economics and Management Sciences, vol. 2, no. 2, pp. 142-145, 2011.

[20] S. A. Adeleke, "Abandonment of Federal Government Low-Cost Housing Estate". HND Thesis, Dept. of Building Technology, Federal Polytechnic, Offa, Nigeria, 2005.

[21] C. Makalah, "Abandoned Construction project," presented at International Conference on Social Sciences and Humanities, 2008.

[22] R. Adeshina, "Abandonment of Construction Projects,". Journal of emerging Trends in Economics and Management Science, vol. 2, no. 2, pp. 142-145, 2010.

[23] P. W. Ihuah, and A. M. Benebo, "An Assessment of the Causes and Effects of Abandonment of Development Projects on Real Property Values In Nigeria," International Journal of Research in Applied, Natural and Social Sciences, Vol. 2, Issue 5, pp. 25-36, 2014.

[24] A. A. Adedibu, and O. A. Akindele, "The Significance of Landed Property Abandonment in Osogbo: A Planner's perspective," Journal of Nigerian Institute of Town Planners, vol. 20, no. 1, pp. 201-202, 2007.

[25] T. A. Ibrahim, "Causes and Effects of Construction Projects Abandonment in Ilorin Metropolis," Scientific Research and Impact, vol. 3, no. 4, pp. 65-74, 2013.

[26] E. O. Abdul, K. O.Raimi, and A. S. Ibisola, "Effects of Abandoned Urban Infrastructure on Environmental Development in Ogun State," Geomatics and Environmental Engineering. vol. 12, no. 3, 2018.

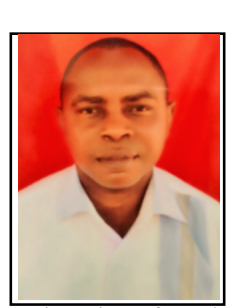

Atamewan, Eugene Ehimatie, was born in Edo State of Nigeria. He holds a Ph.D. Degree in Architecture, Federal University of Technology, Minna, Nigeria in 2018; M.Sc (Arch) in 2001; B.Sc(Arch) in 1999 both from Ambrose Alli University Ekpoma, Nigeria.

He is currently a Senior lecturer/Research fellow, Department of Sustainable Architecture \& Urban Design, Faculty of Architecture, Cross River University of Technology, Calabar, Nigeria. He joined the services of the University in 2007. His wealth of experience cut across architectural practice, teaching and community service.

Dr. Atamewan is a registered Architect with Architects Registration Council of Nigeria (ARCON). He is a member of the Nigerian Institute of Architects (NIA), Association of Architectural Educators in Nigeria (AARCHES) and Nigerian Institute of Management (NIM).

His area of interest covers multidisciplinary research on construction and built environment, building maintenance, sustainable housing, sociocultural Architecture and housing standards. This scholar has several local and international published journal articles in areas such as housing, building maintenance, Landscape planning and sustainable design to his 
European Journal of Environment and Earth Sciences www.ej-geo.org

credit. He is particularly interested in the intersections of architecture, culture and the environment. His seminars, lectures and designs articulate his advocacy for housing delivery for the poor in developing Countries. He is also a reviewer to some local and international journals of repute. 